Красинский Владислав Вячеславович кандидат юридических наук, эксперт Российского общественного института избирательного права (РОИИП)

Источник опубликования: Красинский В.В. Конституционно-правовое регулирование российского гражданства в интересах обеспечения национальной безопасности // Политика и общество. 2006. № 1. С. 63-72; www.krasinskiy.ru

\title{
КОНСТИТУЦИОННО-ПРАВОВОЕ РЕГУЛИРОВАНИЕ РОССИЙСКОГО ГРАЖДАНСТВА В ИНТЕРЕСАХ ОБЕСПЕЧЕНИЯ НАЦИОНАЛЬНОЙ БЕЗОПАСНОСТИ
}

Согласно статье 3 Федерального закона от 31 мая 2002 г. № 62-Ф3 «О гражданстве Российской Федерации» под гражданством Российской Федерации понимается устойчивая правовая связь лица с Российской Федерацией, выражающаяся в совокупности их взаимных прав и обязанностей.

Правовой характер связи между лицом и государством, осуществление взаимных субъективных прав и юридических обязанностей позволяют рассматривать гражданство как конституционное правоотношение между лицом и государством. Это правоотношение регулируется обособленным комплексом правовых норм, который образует самостоятельный конституционно-правовой институт гражданства.

Институт гражданства выполняет двоякую социально-юридическую функцию. С одной стороны, гражданство выступает как средство и способ защиты прав индивида, с другой, как институт защиты прав и интересов государства ${ }^{1}$.

Элементами института гражданства выступают нормы права, содержащиеся в Конституции Российской Федерации, международных договорах, Федеральном законе «О гражданстве Российской Федерации», а

${ }^{1}$ См.: Кутафин О.Е. Российское гражданство. М.: Юрист, 2003. С. 7, 79. 
также принимаемых в соответствии с ними другими нормативными правовыми актами Российской Федерации ${ }^{2}$.

Конституция Российской Федерации устанавливает основные принципы гражданства, основы правового статуса иностранных граждан и лиц без гражданства в Российской Федерации, конституционные права и обязанности граждан России. Регулирование общественных отношений, связанных с гражданством в Российской Федерации, отнесено статьей 71 Конституции к исключительному ведению Российской Федерации ${ }^{3}$.

В ряде международных правовых актов о гражданстве содержатся положения, позволяющие осуществлять конституционно-правовое регулирование правоотношений, связанных с гражданством, с учетом интересов обеспечения национальной безопасности Российской Федерации. Так, в Конвенции о сокращении безгражданства, принятой 30 августа 1961 г., предусмотрено, что «договаривающееся государство предоставляет свое гражданство лицу, рожденному на его территории, которое иначе не имело бы гражданства. Договаривающееся государство может поставить предоставление своего гражданства по ходатайству в зависимость от одного или нескольких условий: ... с) заинтересованное лицо не было осуждено за совершение правонарушения против государственной безопасности и не

2 К числу других нормативных правовых актов относятся: Указ Президента Российской Федерации от 14 ноября 2002 г. № 1325 (в ред. Указа Президента Российской Федерации от 31 декабря 2003 г. № 1545) «Об утверждении положения о порядке рассмотрения вопросов гражданства Российской Федерации» и ведомственные нормативные акты полномочных органов, ведающих делами о гражданстве Российской Федерации (например, Приказ МВД РФ от 19 февраля 2004 г. № 104 «Об организации деятельности органов внутренних дел Российской Федерации при рассмотрении вопросов гражданства Российской Федерации», Приказ МИД РФ от 24 декабря 2002 г. № 18560 «Об утверждении форм решений, заключений и справок по вопросам гражданства Российской Федерации».

3 Регулирование вопросов гражданства является важным суверенным полномочием государства. Поэтому существование гражданства республик в составе Российской Федерации противоречит пункту «в» статьи 71 Конституции, нарушает единство правового пространства и равноправие субъектов Российской Федерации. См. подробней: Кутафин O.E. Указ. соч. С. $183,186,191$. 
приговорено к тюремному заключению на срок пять лет или более по уголовному обвинению»

Международным пактом о гражданских и политических правах, принятом Генеральной Ассамблеей ООН 16 декабря 1966 г., установлено, что каждому, кто законно находится на территории какого-либо государства, принадлежит в пределах этой территории право на свободное передвижение и свобода выбора места жительства. Каждый человек имеет право покидать любую страну. Никто не может быть произвольно лишен права на въезд в свою собственную страну. Эти права могут быть ограничены в исключительных случаях, которые предусмотрены законом и применяются для охраны государственной безопасности, общественного порядка, здоровья или нравственности населения или других прав и свобод и совместимы с признаваемыми в Пакте другими правами.

Непосредственное отношение к обороноспособности и безопасности России имеет Европейская конвенция о гражданстве от 7 ноября 1997 г., регулирующая вопросы воинской обязанности и альтернативной гражданской службы в случаях множественного гражданства. Учитывая наличие договоров Российской Федерации о двойном гражданстве, использование положений соответствующих двусторонних соглашений и Европейской конвенции о гражданстве позволяет регулировать проблемы, связанные с множественным гражданством ${ }^{4}$.

В рамках Содружества Независимых Государств Российская Федерация руководствуется Соглашением между Республикой Беларусь, Республикой Казахстан, Кыргызской Республикой и Российской Федерацией об упрощенном порядке приобретения гражданства от 26 февраля $1999 \Gamma^{5}$. В соответствии с данным Соглашением участвующие стороны предоставляют прибывающим на постоянное жительство на их территории гражданам

4 Такие международные договоры были заключены Российской Федерацией только с Туркменистаном и Таджикистаном. В настоящее время Туркменистан вышел из договора о двойном гражданстве.

${ }^{5}$ См.: С3 РФ. 2002. N 39. СТ. 3643. 
другой стороны право приобретения гражданства в упрощенном порядке, если заявитель ранее состоял в гражданстве Белорусской ССР, Казахской ССР, Киргизской ССР или РСФСР и одновременно в гражданстве бывшего СССР, родился или проживал на территории стороны приобретаемого гражданства до 21 декабря 1991 г., имеет на территории стороны приобретаемого гражданства являющихся еe гражданами близких родственников.

Представляется, что с учетом неблагоприятной демографической ситуации в Российской Федерации важное значение для обеспечения национальной безопасности страны приобретает последовательная и долговременная государственная политика в отношении соотечественников за рубежом, рассчитанная на привлечение в Россию граждан бывшего СССР и предоставление им гражданства. Ключевую роль в этом процессе могли бы играть договоры России с другими государствами на постсоветском пространстве.

В последние годы одним из приоритетов внешней политики Российской Федерации стало сотрудничество с Республикой Беларусь в политической, геостратегической, экономической, оборонной и других областях. Важной составляющей политического объединения России и Белоруссии явилось подписание Договора между Российской Федерацией и Республикой Беларусь от 8 декабря 1999 г. о создании Союзного государства (ратифицирован Федеральным законом от 2 января 2000 г. № 25-Ф3)6. Главой 2 настоящего Договора введен институт гражданства Союзного государства. Согласно статье 14 Договора граждане государств-участников являются одновременно гражданами Союзного государства. Никто не может стать гражданином Союзного государства без приобретения гражданства государства-участника. До принятия союзного нормативного правового акта о гражданстве правовое положение граждан Союзного государства

${ }^{6}$ См.: Рос. газ. 2000. 29 января. 
регулируется национальными законодательными актами государствучастников и договорами между ними.

На уровне национального законодательства Российской Федерации основополагающим нормативным правовым актом, позволяющим осуществлять детальное правовое регулирование отношений гражданства в интересах обеспечения национальной безопасности России, является Федеральный закон от 31 мая 2002 г. № 62-Ф3 «О гражданстве Российской Федерации» ${ }^{7}$.

Глава 2 данного Закона определяет основания и порядок приобретения российского гражданства. Поскольку гражданство выступает важным элементом правового статуса лица, порождает обязанность государства гарантировать права и свободы своих граждан, осуществлять их защиту как внутри страны, так и за рубежом, Закон устанавливает ряд правовых ограничений в интересах обеспечения национальной безопасности ${ }^{8}$. Так, в соответствии со статьей 16 Закона отклоняются заявления о приеме в гражданство Российской Федерации и о восстановлении в гражданстве Российской Федерации, поданные лицами, которые9: а) выступают за насильственное изменение основ конституционного строя Российской Федерации или иными действиями создают угрозу безопасности Российской Федерации; б) в течение пяти лет, предшествовавших дню обращения с заявлениями о приеме в гражданство Российской Федерации или о восстановлении в гражданстве Российской Федерации, выдворялись за пределы Российской Федерации в соответствии с федеральным законом; в) использовали подложные документы или сообщили заведомо ложные сведения; г) состоят на военной службе, на службе в органах безопасности или в правоохранительных органах иностранного государства, если иное не предусмотрено международным договором Российской Федерации; д)

7 Далее - Закон.

8 Данные ограничения соответствуют Европейской конвенции о гражданстве от 7 ноября 1997 г.

${ }^{9}$ См.: СЗ РФ. 2002. N 22. Ст. 2031; 2003. N 46 (ч. II). Ст. 4447. 
имеют неснятую или непогашенную судимость за совершение умышленных преступлений на территории Российской Федерации или за ее пределами, признаваемых таковыми в соответствии с федеральным законом; е) преследуются в уголовном порядке компетентными органами Российской Федерации или компетентными органами иностранных государств за преступления, признаваемые таковыми в соответствии с федеральным законом (до вынесения приговора суда или принятия решения по делу); ж) осуждены и отбывают наказание в виде лишения свободы за действия, преследуемые в соответствии с федеральным законом (до истечения срока наказания).

Помимо ограничений, связанных с приобретением российского гражданства, установленных в интересах обеспечения национальной безопасности страны, Закон предусматривает и поощрительные нормы. Так, согласно части 3 статьи 13 Закона и пункту 12 части 2 Положения о порядке рассмотрения вопросов гражданства Российской Федерации прием в гражданство может осуществляться на основании особых заслуг перед Российской Федерацией. Особыми заслугами перед Российской Федерацией являются выдающиеся достижения в области науки, техники, производства, культуры, спорта, значительный вклад в развитие экономики, обеспечение обороны и безопасности Российской Федерации и другие заслуги, способствовавшие повышению международного престижа России. Решение о предоставлении гражданства Российской Федерации лицу, имеющему особые заслуги перед Российской Федерацией, принимается Президентом Российской Федерации при наличии волеизъявления этого лица. Лица, имеющие особые заслуги перед Российской Федерацией, могут приниматься в гражданство без соблюдения условий, предусмотренных для общего порядка приема в гражданство.

Необходимо отметить, что правовой режим приема в российское гражданство за особые заслуги перед Российской Федерации подразумевается в статье 23 Федерального закона «О внешней разведке». 
В данной статье содержится положение о том, что лицо, оказывающее (оказывавшее) конфиденциальное содействие органу внешней разведки Российской Федерации и не являющееся гражданином Российской Федерации, может быть принято по его ходатайству в гражданство Российской Федерации в порядке, установленном федеральными законами. При этом период сотрудничества лица, принятого в гражданство Российской Федерации, с органом внешней разведки Российской Федерации включается в его трудовой стаж.

Представляется целесообразным ввести аналогичную норму в статью 19 Федерального закона «О федеральной службе безопасности». Очевидно, что подобные правовые положения и реализация их на практике способствуют росту престижа Российского государства, повышают уровень социальноправовой защиты лиц, сотрудничающих (сотрудничавших) с органами разведки и контрразведки Российской Федерации.

Важное значение для конституционно-правового регулирования института гражданства в интересах обеспечения национальной безопасности Российской Федерации имеет прекращение гражданства.

Часть 3 статьи 6 Конституции Российской Федерации указывает, что гражданин Российской Федерации не может быть лишен своего гражданства. Аналогичное положение содержится и в пункте 4 статьи 5 Закона.

Гражданство Российской Федерации может быть прекращено на основании добровольного волеизъявления гражданина о выходе из гражданства или о выборе иного гражданства при изменении Государственной границы Российской Федерации. Выход из гражданства не допускается, если гражданин имеет не выполненное перед Российской Федерацией обязательство, установленное федеральным законом; привлечен компетентными органами Российской Федерации в качестве обвиняемого по уголовному делу либо в отношении его имеется вступивший в законную силу и подлежащий исполнению обвинительный приговор суда; не имеет иного гражданства и гарантий его приобретения. 
Прекращение российского гражданства возможно и по инициативе государства. Решение о приобретении или прекращении гражданства Российской Федерации подлежит отмене, если будет установлено, что данное решение принималось на основании представленных заявителем подложных документов или заведомо ложных сведений. Факт использования подложных документов или сообщения заведомо ложных сведений устанавливается судом.

Думается, что отмена решения по вопросам гражданства должна быть дополнена юридической ответственностью заявителей за представление подложных документов и ложных сведений. С учетом этого предлагается ввести в Кодекс Российской Федерации об административных правонарушениях статью 19.18.1 «Предоставление иностранным гражданином или лицом без гражданства заведомо ложных сведений или подложных документов для получения гражданства Российской Федерации»:

Предоставление иностранным гражданином или лицом без гражданства в полномочный орган, ведающий делами о гражданстве Российской Федерации, заведомо ложных сведений или подложных документов для получения гражданства Российской Федерации, -

влечет наложение административного штрафа в размере от 10 до 25 минимальных размеров оплаты труда».

Отмена решения о приобретении или прекращении гражданства Российской Федерации может быть связана с незаконным содействием должностных лиц органов, ведающих делами о гражданстве. В этой связи представляется целесообразным дополнить Уголовный кодекс Российской Федерации статьей 322.2 «Незаконное содействие в приобретении или прекращении гражданства Российской Федерации». Данная статья может быть сформулирована следующим образом:

«1. Незаконное содействие должностных лиц органов, ведающих делами о гражданстве Российской Федерации, при приеме заявлений, проверке 
фактов, документов и материалов, подготовке заключений и принятии решений по вопросам гражданства Российской Федерации, -

наказывается исправительными работами на срок от 6 месяцев до 1 года, либо лишением свободы на срок до двух лет;

2. Те же деяния, совершенные:

a) в целях совершения преступлений на территории Российской Федерации или за ее пределами;

б) организованной группой либо повлекшие смерть человека или иные тяжкие последствия,

наказываются лишением свободы на срок от пяти до десяти лет».

Перечень оснований отмены решений по вопросам гражданства, предусмотренный статьей 22 Федерального закона «О гражданстве Российской Федерации», следовало бы дополнить незаконным содействием должностных лиц органов, ведающих делами о гражданстве. Данную статью можно после слов «заведомо ложных сведений» дополнить фразой: «а также незаконного содействия должностных лиц органов, ведающих делами о гражданстве Российской Федерации».

Отмена решения по вопросам гражданства Российской Федерации осуществляется Президентом Российской Федерации или иным полномочным органом, ведающими делами о гражданстве Российской Федерации и принявшими такое решение.

В соответствии со ст. 28 рассматриваемого Закона, полномочными органами, ведающими делами о гражданстве Российской Федерации, являются: Президент Российской Федерации; федеральный орган исполнительной власти, ведающий вопросами внутренних дел, и его территориальные органы; федеральный орган исполнительной власти, ведающий вопросами иностранных дел, дипломатические представительства и консульские учреждения Российской Федерации за рубежом. В этом перечне необоснованно отсутствует Федеральная Служба безопасности Российской Федерации и территориальные органы безопасности. 
Между тем, согласно пункту «р» статьи 12 Федерального закона от 3 апреля 1995 г. № 40-Ф3 (в ред. Федерального закона от 30 июля 2003 г. № 86Ф3 «О федеральной службе безопасности», пунктам 12, 29, 35-37 «Положения о порядке рассмотрения вопросов гражданства Российской Федерации», утвержденного Указом Президента Российской Федерации от 14 ноября 2002 г. № 1352 (в ред. Указа Президента РФ от 31.12.2003 N 1545), пункту 36 «Положения о Федеральной службе безопасности», утвержденного Указом Президента Российской Федерации от 11 августа 2003 г. № 960, пунктам 7, 10 и 21 Приказа МВД РФ от 19 февраля 2004 г. № 104 «Об организации деятельности органов внутренних дел Российской Федерации при рассмотрении вопросов гражданства Российской Федерации» Федеральная служба безопасности Российской Федерации и территориальные органы безопасности принимают участие в решении вопросов гражданства. Более того, в соответствии с Указом Президента Российской Федерации от 14 ноября 2002 г. № 1352 в целях координации действий по исполнению Федерального закона «О гражданстве Российской Федерации» МВД Российской Федерации, МИД России и ФСБ России издана межведомственная инструкция от 30 ноября 2002 г. об их взаимодействии при рассмотрении вопросов гражданства ${ }^{10}$.

Согласно пунктам 35, 36 Положения о порядке рассмотрения вопросов гражданства Российской Федерации и в целях выявления оснований для отклонения заявлений об изменении гражданства подразделения паспортновизовой службы МВД, ГУВД, УВД субъектов Российской Федерации, ГУВД на режимных объектах Службы общественной безопасности МВД России запрашивают заключения территориальных органов безопасности при рассмотрении заявлений в общем порядке или осуществляют согласование при рассмотрении заявлений в упрощенном порядке ${ }^{11}$. После проведения

${ }^{10}$ См.: С3 РФ. 2002. N 46. Ст. 4571; 2004. N 1. Ст. 16.

${ }^{11}$ Решения по заявлениям об изменении гражданства детей в возрасте до 14 лет и недееспособных лиц принимаются полномочными органами без 
проверки территориальные органы безопасности направляют заключение запрашивающему органу. При наличии оснований для отклонения заявления, предусмотренных статьями 16 и 20 Федерального закона «О гражданстве Российской Федерации», территориальные органы письменно информируют о наличии этих оснований.

Для получения заключения ФСБ России материалы (вместе с заключением МВД России) направляются Паспортно-визовым управлением Службы общественной безопасности МВД России в Управление регистрации и архивных фондов ФСБ России (УРАФ ФСБ России). После дополнительной проверки собранные документы и материалы, включая заключения МВД и ФСБ России, направляется в Комиссию по вопросам гражданства при Президенте Российской Федерации для предварительного рассмотрения и подготовки предложений Президенту Российской Федерации.

Согласование решений о приеме в гражданство Российской Федерации в упрощенном порядке осуществляется с территориальным органом безопасности по месту жительства заявителя.

Заявление об изменении гражданства в упрощенном порядке, поданное лицом, проживающим за пределами Российской Федерации, направляется дипломатическими представительствами и консульскими учреждениями Российской Федерации в Департамент Консульской службы МИД России.

Департамент Консульской службы МИД России направляет материалы для согласования в МВД России и в УРАФ ФСБ России, который проводит проверку необходимых сведений и документов. В случае выявления фактов, свидетельствующих о наличии оснований для отклонения заявлений о приеме в гражданство Российской Федерации и восстановлении в гражданстве Российской Федерации либо для отказа в выходе из гражданства Российской Федерации, ФСБ России или ее территориальные органы согласования с ФСБ России и ее территориальными органами и без проведения проверок органами внутренних дел. 
информируют об этом в письменной форме соответствующий полномочный орган.

Таким образом, комплексный анализ нормативных правовых актов, регулирующих отношения, связанные с гражданством Российской Федерации, свидетельствует об активном участии органов федеральной службы безопасности в решении вопросов гражданства. В связи с изложенным часть 1 статьи 28 Федерального закона «О гражданстве Российской Федерации» представляется целесообразным дополнить предложением «федеральный орган исполнительной власти, ведающий вопросами безопасности, и его территориальные органы».

Учитывая, что полномочия органов, ведающих делами о гражданстве Российской Федерации, определяются Федеральным законом «О гражданстве Российской Федерации» (ст. ст. 29-31), главу 6 комментируемого закона следовало бы дополнить статьей $31^{1}$ «полномочия федерального органа исполнительной власти, ведающего вопросами безопасности, и его территориальных органов» или часть 2 статьи 28 Закона дополнить словосочетанием «и другими федеральными законами».

Глава 8 Федерального закона «О гражданстве Российской Федерации» регулирует порядок обжалования решений по вопросам гражданства Российской Федерации. Однако Законом не предусмотрена ситуация, связанная с предоставлением заявителю в ходе обжалования документов и материалов, послуживших основанием для отклонения заявления о приеме в гражданство (о восстановлении в гражданстве Российской Федерации), а также отказа в выходе из российского гражданства. Было бы логичным дополнить статью 39 Закона частью 2:

«Законность обжалуемого решения, а также объем представляемых заявителю материалов и документов, полученных полномочными органами, ведающими делами о гражданстве Российской Федерации, в связи с принятием решения о гражданстве, определяется судом с учетом требований 
обеспечения защиты конституционного строя и безопасности Российской Федерации».

Как отмечалось ранее, обладание российским гражданством имеет для лица ряд важных правовых последствий, непосредственно связанных с интересами обеспечения национальной безопасности Российской Федерации. Только гражданин Российской Федерации, согласно части 2 статьи 6 Конституции, обладает на ее территории всеми правами и свободами и несет все предусмотренные ею обязанности.

В соответствии со статьей 14 Федерального закона «О правовом положении иностранных граждан в Российской Федерации» иностранные граждане не имеют права находиться на государственной или муниципальной службе, быть членами экипажей военных кораблей Российской Федерации, заниматься иной деятельностью и замещать иные должности, допуск иностранных граждан к которым ограничен федеральным законом ${ }^{12}$.

Отсутствие гражданства Российской Федерации не позволяет лицу быть принятым на работу на объекты и в организации, деятельность которых связана с обеспечением безопасности России. Перечень таких объектов и организаций утверждается Правительством Российской Федерации.

Кадровый состав правоохранительных органов и органов безопасности формируется из числа российских граждан. Статьей 7 Федерального закона «О Федеральной службе безопасности», статьей 17 Федерального закона «О внешней разведке», статьей 18 Федерального закона «О государственной охране», статьей 40.1 Федерального Закона «О прокуратуре Российской Федерации», статьями 17 и 19 Закона РФ «О милиции» предусмотрено, что на службу в органы федеральной службы безопасности, органы внешней разведки, органы государственной охраны, в органы прокуратуры, на службу в милицию принимаются только граждане Российской Федерации.

12 Об особенностях правосубъектности иностранных граждан см.: Авакьян С.А. Гражданство Российской Федерации. М., 1994. С. 5-12. 
Следует отметить, что статьями 32-34 Федерального закона (в ред. от 11 ноября 2003 г. № 141-Ф3) «О воинской обязанности и военной службе» определена возможность для иностранных граждан в возрасте от 18 до 30 лет, законно находящихся на территории Российской Федерации и владеющих русским языком, заключать первый контракт о прохождении военной службы на воинских должностях, подлежащих замещению солдатами, матросами, сержантами и старшинами в Вооруженных Силах Российской Федерации, других войсках и воинских формированиях сроком на пять лет. После трех лет военной службы по контракту при продолжении службы в Вооруженных Силах Российской Федерации, других войсках и воинских формированиях, граждане государств, входивших в состав СССР, вправе обратиться с заявлениями о приеме в гражданство Российской Федерации и после приобретения российского гражданства они пользуются всеми правами как граждане Российской Федерации и могут при желании продолжить военную службу. Данная норма имеет целью кадровое комплектование Вооруженных Сил и войск Российской Федерации, а также привлечение в Россию граждан бывшего СССР и предоставление им гражданства ${ }^{13}$. Вместе с тем существуют определенные сомнения в лояльности военнослужащих-иностранцев Российской Федерации при выполнении боевых задач на территориях государств, гражданами которых они являются. Аналогичная проблема возникает и в связи с необходимостью отражения возможной вооруженной агрессии.

Существенное влияние на правовой статус лица оказывает наличие двойного гражданства.

Под двойным гражданством понимается приобретение лицом с ведения государства, гражданином которого оно является, второго гражданства. Получение двойного гражданства должно быть предусмотрено

${ }^{13}$ См. Приказы Министра Обороны Российской Федерации от 2 апреля 2004 г. № 101 «О сроке временного пребывания в Российской Федерации иностранных граждан, поступающих на военную службу по контракту» и от 3 июня 2004 г. № 168 «Об утверждении формы ходатайства о приеме в гражданство Российской Федерации». 
международным договором Российской Федерации или федеральным законом. Получение гражданства другого государства иным путем не признается Российской Федерацией: гражданин Российской Федерации, имеющий также иное гражданство, рассматривается Российской Федерацией только как российский гражданин ${ }^{14}$. Данное положение закреплено частью 1 статьи 6 Федерального закона «О гражданстве Российской Федерации» и соответствует статьям 7, 14 и 15 Европейской конвенции о гражданстве.

Приобретение иностранными гражданами российского гражданства допускается при условии их отказа от прежнего гражданства (отказ не требуется, если это предусмотрено международным договором или федеральным законом, а также в силу его невозможности по независящим от лица причинам (пункт «г» части 1 статьи 13 Закона). Если отказ от имеющегося гражданства связан с приобретением российского гражданства, дается обязательство в течение 1 года со дня приобретения гражданства Российской Федерации представить документ о выходе из иного гражданства. Если иное гражданство прекращается вследствие приобретения гражданства Российской Федерации, дается обязательство представить соответствующий документ в течение 3 месяцев со дня приобретения российского гражданства.

Однако правовое регулирование приобретения российского гражданства иностранными гражданами не всегда отличалось четкостью и последовательностью. В частности, с момента вступления в силу Закона Российской Федерация от 17 июня 1993 г. № 5206-1 «О внесении изменений и дополнений в закон РСФСР «О гражданстве РСФСР» до 1 июля 2002 г. в России легально существовала практика приобретения российского гражданства иностранными гражданами без отказа от имеющегося гражданства.

14 Проблема «незаконного» двойного гражданства приобрела особую актуальность в связи с назначением на должность заместителя Секретаря Совета безопасности Российской Федерации Березовского Б.А., имеющего помимо российского гражданства гражданство Израиля. 
Признание Россией двойного гражданства породило ряд проблем, связанных с обеспечением национальной безопасности России ${ }^{15}$.

Примером может служить статья 21 Закона Российской Федерации «О государственной тайне» и пункт 3 Положения о порядке допуска лиц, имеющих двойное гражданство, лиц без гражданства, а также лиц из числа иностранных граждан, эмигрантов и реэмигрантов к государственной тайне, утвержденного Постановлением Правительства Российской Федерации от 22 августа $1998 \Gamma^{16}$. Так, лица, имеющие двойное гражданство, приобретенное в соответствии с законом, получают допуск лишь к сведениям, составляющим государственную тайну с грифом «секретно», а «незаконные» бипатриды вообще лишены такого права. Согласно статье 22 Закона «О государственной тайне» основанием для отказа должностному лицу или гражданину в допуске к государственной тайне являются: а) постоянное проживание его самого и (или) его близких родственников за границей и б) выявление в результате проверочных мероприятий действий оформляемого лица, создающих угрозу безопасности Российской Федерации. Понятно, что по этим основаниям ни одно лицо, имеющее двойное гражданство, не может, да и не должно быть уравнено в правах с лицами, имеющими только российское гражданство ${ }^{17}$.

Вместе с тем указанные правовые ограничения противоречат части 2 статьи 62 Конституции Российской Федерации, поскольку наличие у российского гражданина гражданства иностранного государства не умаляет его прав и свобод.

15 Ряд ведущих государствоведов (В.С. Шевцов, О.Е. Кутафин) подвергли двойное гражданство обоснованной критике. Так, В.С. Шевцов считает двойное гражданство нарушением государственного суверенитета, поскольку тем самым подрывается осуществление полной юрисдикции суверенной государственной власти над своими гражданами. О.Е. Кутафин отмечает, что интерес к приобретению двойного гражданства проявляют представители криминалитета, готовые в случае угрозы своим материальным и нематериальным благам выехать на постоянное место жительства за границу.

${ }_{16}^{16}$ См.: СЗ РФ. 1998. N 35. Ст. 4407.

${ }^{17}$ См. также: Свинарев B.B. К вопросу о правовом регулировании статуса лиц с двойным гражданством // Право и политика. 2001. № 2. 
Важное значение для интересов обеспечения национальной безопасности России имеет конституционно-правовое регулирование отношений, связанных с гражданством, в сфере избирательного права.

В соответствии с Конституцией Российской Федерации Президентом Российской Федерации, депутатами Государственной Думы Федерального Собрания Российской Федерации могут быть граждане Российской Федерации. Аналогичные требования к высшим должностным лицам и депутатам законодательных органов власти субъектов Российской Федерации содержатся в конституциях и уставах субъектов Российской Федерации.

Согласно статье 12 Федерального закона «О правовом положении иностранных граждан в Российской Федерации», иностранные граждане в Российской Федерации не имеют права избирать и быть избранными в федеральные органы государственной власти, органы государственной власти субъектов Российской Федерации, а также участвовать в референдуме Российской Федерации и референдумах субъектов Российской Федерации.

Вместе с тем анализируемый закон, а также федеральное законодательство о выборах предоставляют постоянно проживающим в Российской Федерации иностранным гражданам право избирать и быть избранными в органы местного самоуправления, а также участвовать в местном референдуме ${ }^{18}$.

В интересах национальной безопасности Российской Федерации представляется целесообразным ограничить пассивное избирательное право иностранных граждан. Указанное обстоятельство обусловлено наличием значительных по численности иностранных диаспор в регионах с малочисленным российским населением (Приморский край, Хабаровский край, Амурская, Сахалинская, Читинская области). Массовое вовлечение иностранцев в управление делами государства и решение вопросов местного

18 См.: Ст. 12 Федерального закона от 25 июля 2002 г. № 115-Ф3 «О правовом положении иностранных граждан в Российской Федерации», п. 10 ст. 4 Федерального закона от 12 июня 2002 г. (с изм. от 4 июля 2003 г.) № 67Ф3 «Об основных гарантиях избирательных прав и права на участие в референдуме граждан Российской Федерации». 
значения при отсутствии комплексных долгосрочных программ развития указанных субъектов Российской Федерации может повлечь постепенное отстранение федеральных органов государственной власти и органов государственной власти субъектов от государственного управления, усиление сепаратистских тенденций и дальнейшую трансформацию в автономные образования с перспективой территориального отторжения. Это подтверждается и негативным зарубежным опытом (референдумы о сецессии провинции Квебек в Канаде). Представляется преждевременным предоставление иностранцам пассивного избирательного права в пограничных зонах, на территориях с регламентированным посещением иностранных граждан, в закрытых административно-территориальных образованиях, а также в анклавной территории Калининградской области.

Думается, что в федеральных законах о выборах необходимо ограничить возможность избрания Президентом Российской Федерации или депутатом Государственной Думы Федерального Собрания Российской Федерации лиц, имеющих двойное гражданство. В соответствии со статьей 62 Конституции Российской Федерации наличие у гражданина Российской Федерации гражданства иностранного государства не умаляет его прав и свобод, если иное не предусмотрено федеральным законом. Федеральные законы «О выборах Президента Российской Федерации» и «О выборах депутатов Государственной Думы Федерального Собрания Российской Федерации» каких-либо ограничений в данной ситуации не предусматривают. Гражданин Российской Федерации, одновременно имеющий гражданство иностранного государства, может участвовать в выборах и быть избран Президентом России или депутатом Государственной Думы. С учетом этого предлагается включить в пункт 2 статьи 3 Федерального закона «О выборах Президента Российской Федерации» и в пункт 2 статьи 5 Федерального закона «О выборах депутатов Государственной Думы Федерального Собрания Российской Федерации» после слов «...может быть избран гражданин 
Российской Федерации...» словосочетание «не имеющий гражданства иностранного государства».

Предложенные ограничения не только дополняют положения о том, что прекращение российского гражданства либо приобретение гражданства иностранного государства являются основанием для прекращения государственной гражданской службы Российской Федерации, но и позволяют логически развивать систему защиты государственной власти от возможного использования должностных полномочий в ущерб интересам безопасности России ${ }^{19}$. В связи с разработкой проекта Федерального закона «О правоохранительной службе» представляется целесообразным включить в него положения о прекращении правоохранительной службы в случае прекращения российского гражданства либо приобретения гражданства другого государства.

Проведенный анализ конституционно-правового регулирования института гражданства в интересах национальной безопасности России позволяет сделать вывод о необходимости дальнейшего совершенствования государственной политики в области гражданства.

Развитие института российского гражданства представляется целесообразным привести в соответствие с требованиями Конституции Российской Федерации. В частности, не является конституционным существование гражданства республик в составе Российской Федерации. Наличие республиканского гражданства противоречит положениям Конституции о суверенитете Российской Федерации и верховенстве федеральных законов (части 1 и 2 статьи 4), о равноправии субъектов

19 См. ст. 16 Федерального закона от 27 июля 2004 г. № 79-Ф3 «О государственной гражданской службе Российской Федерации», ст. 4 Федерального закона от 8 мая 1994 г. № 3-Ф3 (в ред. Ф3 от 21 июля 2005 г. № 93-Ф3) «О статусе члена Совета Федерации и статусе депутата Государственной Думы Федерального Собрания Российской Федерации», ст. 14 Закона РФ от 26 июня 1992 г. № 3132-1 (в ред. Ф3 от 20 июня 2000 г. № 89-Ф3) «О статусе судей в Российской Федерации», ст. 43 Федерального Закона от 17 января 1992 г. № 2202-1 (с изм. от 22 августа 2004 г.) «О прокуратуре Российской Федерации». Как уже отмечалось выше, иностранные граждане вправе проходить военную службу на должностях, замещаемых солдатами, матросами, сержантами и старшинами. 
Российской Федерации (части 1 и 4 статьи 5), о едином и равном гражданстве независимо от оснований его приобретения (часть 1 статьи 6), об отнесении вопросов гражданства к исключительному ведению Российской Федерации (пункт «в» статьи 71).

Недостаточно обоснованным и правомерным является отсутствие в перечне полномочных органов, ведающих делами о гражданстве Российской Федерации, Федеральной Службы безопасности Российской Федерации и территориальных органов безопасности.

Важное значение для интересов обеспечения национальной безопасности России имеет конституционно-правовое регулирование отношений, связанных с двойным гражданством. В первую очередь это касается допуска лиц, имеющих двойное гражданство, лиц без гражданства, а также лиц из числа иностранных граждан, эмигрантов и реэмигрантов к государственной тайне. Учитывая наличие в Российской Федерации категории лиц, получивших в период с 1993 по 2002 гг. помимо гражданства Российской Федерации гражданство других государств (т.н. «незаконные бипатриды»), актуальным является закрепление в федеральных законах о выборах и проекте Федерального закона «О правоохранительной службе» правовых ограничений, касающихся невозможности избрания этих лиц, а также прекращения ими федеральной государственной службы и государственной службы субъектов Российской Федерации в связи с наличием гражданства других государств. Следовало бы ввести в Кодекс Российской Федерации об административных правонарушениях статью 18.12.1 «Уклонение российского гражданина от предоставления сведений о наличии (получении) гражданства (подданства) иного государства»:

«Уклонение российского гражданина от предоставления в полномочный орган, ведающий делами о гражданстве Российской Федерации, сведений о наличии (получении) гражданства (подданства) иного государства, -

влечет наложение административного штрафа в размере от 10 до 25 минимальных размеров оплаты труда». 
Представляется целесообразным установить административную ответственность иностранных граждан и лиц без гражданства за предоставление заведомо ложных сведений или подложных документов для получения гражданства Российской Федерации, а также ввести уголовную ответственность должностных лиц органов, ведающих делами о гражданстве, за незаконное содействие в приобретении или прекращении российского гражданства. Перечень оснований отмены решений по вопросам гражданства, предусмотренный статьей 22 Федерального закона «О гражданстве Российской Федерации», следовало бы дополнить незаконным содействием должностных лиц органов, ведающих делами о гражданстве.

В формате Союзного государства (Россия - Республика Беларусь) одним из приоритетов должна стать разработка национального и союзного законодательства, устанавливающего основания, порядок приобретения и прекращения гражданства Союзного государства, детализирующего правовое положение граждан Союзного государства. 